\title{
The Dilemma of Islamic Education and Prostitution Life
}

\author{
Waza Karia Akbar \\ STKIP PGRI Sumatera Barat, Padang \\ wazasolok@gmail.com \\ Yuhelna \\ STKIP PGRI Sumatera Barat, Padang \\ lenayuhelna86@gmail.com

\section{Sri Rahmadani} \\ STKIP PGRI Sumatera Barat, Padang \\ srirahmadani118@gmail.com
}

\begin{abstract}
The Minangkabau society is famous for the tradisional philosophy of adat basandi sarak, sarak basandi kitabullah (ABS-SBK). Education and religious values have been passed down from one generation to another. However, it is still not going well. It is seen with the many women who are trapped in negative terms. They are very weak people in the economy and religious education. The goal to be achieved in this study in find out the causes of Minangkabau women who are continually involved in the world prostitution. The focus of this research is the woman in the localization of the goddess Aro, West Sumatera. The method used by researchers is qualitative with case studies in the Andam Dewi. The findings suggest that those involved in prostitution were women aged 17-27 years old because of the economic factors and religious knowledge are very weak. Other findings also show the weak role of Mamak in Minangkabau in monitoring its ministry.
\end{abstract}

Keywords: Islamic, religious, education, social interaction, prostitution

How to Cite: Akbar, Waza Karia, Yuhelna and Sri Rahmadani. 2021. The Dilemma of Islamic Education and Life of WTS Andam Dewi Aro Suka. Vol 5 (1): pp. 1-10. DOI: https://doi.org/10.24036/jess.v5i1

\section{Introduction}

Human life lives in modern times changed due to technological advances. With technolo-gical advances people have left religious values that have been embraced. It is famous for the traditional philosophy of Adat Basandi Sarak, Sarak Basandi Kitabullah (ABS-SBK). The woman is taking care of her honor in interacting with the community. Increasing the population will cause socio-economic problems in which individuals or groups of individuals will now find it increasingly difficult to find employment. It is increasingly encouraged by the background of such poor religious education, not going to school, just completing elementary level school. Another cause is that a person does not have competent ability in the office. The weakness of religion and lack of social support from the families of women Minang faced a dilemma in his life. 
The role of governments that are still weak in managing those who do not work causes them to form their own groups so that they refrain from society. The rejection and stereotypical inherent to women who did not work resulted in the community experiencing a decline in identity, thereby resigning from the social environment and experiencing obstacles in social adjustment and self-development. Living under the pressures of the environment and the distant family of Islamic religious education. That is the dilemma of the woman Minangkabau at this time. It should also accept a variety of negative stereotypes aimed at them but their intended views are not necessarily true. For example, we take the example in that they get educational skills and religious education. People always think that someone who works as is a woman who is despised, dirty, disgusting like a man who has no feeling. Same with other humans, where they have a desire to achieve the meaning of life and that is reflected in the sense of life. As feeling the happiness that is loved or cared for by others, and loving others, who are rewarded as others in general, are given the same opportunity in achieving prosperity in the field of economics is what makes conscious or unconscious finding meaning in life for itself. That is the dream of a handful of Minangkabau women.

The Association of female Minang is far from the values and norms of religion, so that many are trapped in a circle of intercourse that is not bagaus. As easily invited by friends in a free association. So that appears a negative stigma from the surrounding community. They always live under pressure, so they separate themselves from society. Isolated life certainly affects the different meanings of other humans. Therefore it is necessary to scrutinized the meaning towards themselves and the social environment. And the weak cause of religious value in society. Until the astronaut ABS-SBK. Travel to discover what they can give in their lives, what can be taken from their journey so far, and what attitudes are given to the provisions or fate that they may change, all of which are not separated from whatever is desired during life, as well as any obstacles faced by in achieving the meaning of life (K. Kartono, 2014). It can be seen from $60 \%$ which are netted in their general raids which are suppressed by economic needs as well as very weak religious education. Most of the caught women are Minangkabau people. That strongly prioritizes the philosophy of Islamic education.

\section{Literature Review}

The term religious education consists of two words, namely education and religion. Education is a human effort to bring the child to the level of maturity in the sense of being aware of taking responsibility for all actions morally. In educational psychology, it is stated that education is "a process of growth that takes place by the act of (Ramayulis, 2004). Basically, the term education has a very broad meaning, so that until now there is no uniform definition or definition of education provided by experts. Each education expert is still very much influenced by their own mindset in providing the meaning of education. According to Ahmad Tafsir in his book Science of Education in an Islamic Perspective, states that "Islamic education is a science based on Islam which contains a set of teachings about human life, and these teachings are based on the Qur'an and hadith (Ahmad Tafsir, 2004). 
Research conducted by Seno Tri Bayu Aji, it is known that the results of library servicescRoving is very effective. This can be seen from the large number of visitors who becomecmembers of the mobile library. Although there are still disadvantagescsubmitted by the informants, including the number and diversity of collections, timecVisits and services that are deemed not enough to meet the needs of users at Localization area of Gambilangu Semarang. Most of the informants were of the opinion positive about this Mobile Library Service that serves in the region Gambilangu Semarang (Aji, S. T. B., \& Heriyanto, 2013). Research conducted by Sri Rahmadani explains that the Agency Structure Analysis of Multiple Income Sources for Poor Farmers, especially women, is in accordance with the provisions. Women who work in their daily life must work optimally to avoid poverty so that they have multiple jobs (Sri Rahmadani, 2017).

Localization closure is not an easy matter, so it requires a lot of effort sustainable which combines the synergy of various government agencies, society and also Non Government Organization. This study aims to explore the technicalities of closure localization of kedung banteng, which became the 46 localization that was officially closed, how are the strategic steps. This study uses research methods descriptive, by analyzing primary and secondary data, in the form of observation, documentation, and Interview result. The closing process was carried out after several legal regulations were issued. In general, the closing process has been completed, but then several related problems arise the existence of ex-commercial sex workers which is difficult to control, because of several programs considered ineffective. In fact, there are a lot of unfinished issues related to it compensation funds provided to ex-commercial sex workers other than the amount that is not the same, the workers felt the funds provided were minimal, however the localization closure process has been successfully implemented. Sociologically this policy affect the surrounding community and also the former commercial workers who started it life \& new ventures for his survival (Dewi, Dian Suluh Kusuma, 2019).

This research was conducted in late 2019. In this study it was found that the religious factor adhered to by a person involved in a job that is not in accordance with religious principles has a very large influence. Previous research was also conducted by Erianjoni who examined prostitutes in the city of Padang (Erianjoni, 2012). The fundamental difference and novelty in this research is that those involved in and caught by the civil service police (SATPOL PP) are old players. Then the brand will be isolated to Andam Dewi who is in Aro likes. From the results of the interview, it can be found that the religious factor is a very important thing. those who were screened were those whose religious education was very minimal. they received religious education only as a child. Invitation from peers is a major factor. So this research focuses on seeing that Islamic religious education adopted in the Minangkabau customary philosophy is still not optimal.

\section{Method}

This Study uses qualitative research methods used in data collection and data analysis. The Reason researchers choose this qualitative approach because this approach is felt to be able to define and explain the social situation and the 
phenomenon of meaning towards themselves and the social environ-ment. The symptoms referred to include behaviors, motives, subjects understand and interpret the life-related activities undertaken by in interpreting themselves and the social environment. The type of research that researchers use to interpret themselves and the social environment is a realistic phenome-nology. This type emphasizes universal search for problems of various objects that include human action, their motives for their personal actions and values (J. Moleong, 2007).

The theory used to study this problem was the symbolic theory there was (symbolically there) proposed by Herbert Blumer. According to the Blumer, there is a symbolic referring to the specific nature of the interactions between ( $\mathrm{J}$. Moleong, 2007) humans, which is that human beings translate and define actions with each other. Interactions between individuals are mediated by the use of symbols, interpretations or by trying to understand each other's meaning of each other's actions. The process of interpretation here is the process of thinking, mediation between stimulus and response. The symbolic interactionism theory has an interest in stimulus and response but emphasizes the interpretation process given by individuals to the stimulus that comes (Emzir, 2012). In the interpretation process, stimulus that is entered and received or directed at an individual will be interpreted and judged to select and decide which stimulus to respond to. Why so weak Islamic education in the life of the Minangkabau women at the moment. So it needs a very thorough approach in this theory (Afrizal, 2014).

\section{Result and Discussion}

Based on data obtained from the results of the study, there is localized by the Andam Dewi who is not in the bonds of marriage, is over 17 years old, and no longer a virgin. Based on the data obtained from Mr. Zulkarnaen who just collected data, it turns out that Andam Dewi is derived from various regions. From West Sumatra 60\%, 15\% East Java, 15\% Central Java and the remaining 10\% from Jambi, Lampung, Bengkulu, Medan, Pekanbaru, Aceh and Sulawesi. Based on research, there is information that there are some of the districts of Solok, this is because this localization is the largest and most famous in West Sumatera so they are afraid to meet relatives, friends or neighbors who will know their job as. From the data is more than half a Mingkabau woman who strongly uphold the traditional philosophy of Adat Basandi Sarak, Sarak Basandi Kitabullah (ABS-SBK). Income earned in a job is very influential on relationships and interactions with other people. people who have higher income will get more recognition from their friends in society (Akbar, 2018).

More than half the population of the orphanage Andam Dewi Solok is a woman who is netted by the officers and entrusted by Satpol PP City of Padang to undergo construction, "said the head of the orphanage, the Shahbana in Arosuka, on Tuesday. During his training at the Dewi Solok orphanage, according to her, the orphanage residents were given various skills in addition to understanding the religious and social values of society. He said the provision of skills for orphanages so that after undergoing training they can live independently by utilizing existing skills. "It is hoped that after undergoing guidance in the orphanage, they will no 
longer live as prostitutes. But the fact is not uncommon for those who are netted by officers to enter and leave many times, "he said (Asmaini, 2018). Still in the same year, 2018, when the raid was carried out again, 40 the target women who inhabited the orphanage at Andam Dewi Solok, West Sumatra, 24 of which had been netted in the raid held in the city of Padang. In general, a netted raid is an old player. They are again involved in the world of prostitution due to economic factors. They do not have the ability and skills to work in everyday life.

New patterns of migration challenge China to face the need to provide health care to increasingly diverse populations. The Chinese government has the experience of managing health implications from rural migration to urban massively. Some common themes characterize foreign and internal migrant populations, including social exclusion, econo-mic vulnerability, limited health insurance, and mental health pressures. Research growth Momentum and policies in the areas of internal migration can be applied to improve services for African migrants. In addition, the Chinese government recently launched the first phase of the National health Care reform plan that aims to achieve comprehensive universal health coverage by 2020. One of the main objectives of Chinese health reform is to promote equity health, which will require improved quality of care for foreign migrants and other populations that have been buried in the Chinese health system. Applying a health diplomacy approach to African migrants in China is a potentially effective strategy, and one that harmonizes well with China's economic interests and with the Chinese tendency to assume a larger role as a donor country and a global health leader (M. M. McLaughlin, M. C. Lee, B. J. Hall, M. Bulterys, L. Ling, 2014).

The factor that causes someone to be a prostitute, first is to avoid the difficulties of life, and get pleasure through the short path. Secondly, there is a lack of understanding, education and illiteracy, which justifies prosti-tution. Third is to be a sex worker does not require skill/skill, does not require high intelligence, easy to do. The four main assets of this work are beauty and courage. Fifth, there is economic pressure, poverty factor, there is economic consideration to sustain their survival (K. Kartono, 2014). With the weak knowledge of religion that has caused the women to be very easy to fall in the circle of association that is not good. A job as a farmer is better than working with an unclear income. Farmers at work can generate income of around $\mathrm{Rp}$. 50,000 in a day. thus in rural areas the main occupation of the community is clear, rather than jobs such as scavengers and prostitutes (Akbar, 2019).

Moral actually cannot be separated from the local socio-cultural influence that is believed to be true. The use of half-naked (sorry) clothes for women in Indonesia may be considered to violate the moral rules of people from the east, but this rule may not apply to women in the West who are used to doing it because it has become their habit (Budi Juliardi, 2014). The social problems of prostitution and prostitution are increasingly complex. It is triggered by several factors, such as the poverty factor, lack of education, and lacks expertise. One of the interventions that can be done with social rehabilitation. This social rehabilitation aims to restore the former function to the social environment, in addition to rehabilitation also aims to give skills and expertise in order not to return in the world of prostitution. The role 
of social worker is needed in this case, because social rehabilitation is one of the natural social Work practices (W. S. Ramadhani, S. Sulastri, 2017). Education in life is very important, especially religious education. It is very interesting because if we see and compare those involved in the world of prostitution is an area that uphold Islamic religious education.

The information obtained from Rama's mother above explains the work of only thinking about themselves regardless of the other disadvantaged parties. The fact proves that the interpretation of people is not all right like that. Is the same as the individual or group of people who have meaning in achieving meaning in life. Being not the choice of their life but something they have to live in order to support their families. As well as the absence of their education about the religion of Santa is adequate so that it is so easy to be tempted by the world of social relations that are not good. As stated by KK (33 years) working as, the following are: "In fact, who is in this world who is born to work so? KK Kayaking is also because already trauma 3 times have a husband but still life aja hard. Where to change the parents ' children, especially the children of KK so that they translated this work, I know about religion, but my curiosity is very limited. And there is no one who teaches the religion in detail to me".

Compassion and responsibility make a risk of self-esteem in order to support the family. To, comment and insult to the work they do is not so important. This is according to what SN (26 years) says it works as, following its explanation: "We people so to support us people have 3 children, my education just SMP Elementary School, my knowledge of religion does not exist. Our children do not have fathers. If they have anyone who finances us do not want to work, as. He can only go to us, but can not help how we have the way out of literature".

Based on SN and the same narrative is also obtained from IK (20 years) and WT (22 years), that they actually do not want this job. However, in order to revive the families they are willing to take the decision to be. Working as income is uncertain, but the income they gained is used to support their families. They appreciate their work as they believe this work can support them. They consider working as being able to earn a lot of money easily in addition they can also get pleasure. In this case there should be a role of Mamak, because they can help the of those involved in the problems that exist in society.

Economic factors and weak religious knowledge also affect women working in the field of prostitution. Some came from poor families, partly abandoned by their husbands while their children had to continue to eat, others had to pay for their parents ' care, partly forced by their husbands because they were very poor in life. Similar to the recognition of some, which is actually if they can vote, they do not want to be, but what strength, they have no intelligence or skill. Human Trafficking in 2013 reports commissioned by THE U.S. Department of State put Thailand on the highest spectacle list for the fourth consecutive year. The state in this ranking does not fully conform to the minimum standards for eliminating Trafficking that is detailed in the ACT of the victim's Trafficking 2000 but trying to be so. Thailand has managed to pass downgrade to Tier 3 because the government has carved out a plan that will meet the minimum ACT standards. The report also draws attention to the fact that many of those who are persuaded and through Thailand are involved 
in sex work. Panjit Kaewsawang is an Offi CER program from the Bangkok Action Aid Offi CE and works with women who have been traffic taunted to Thailand. Speaking to The Lancet he explains, "Thailand is a hub. People travel from their home country to Thailand or through Thailand to reach their Fi destinations like other parts of southeast Asia or the Middle East (S. Barmania, 2013)".

According to the Blumer (Ritzer, George dan Goodman, 2010), one of the seven principles there is symbolic is that people can modify or alter the meanings and symbols they use in their actions and interactions based on their interpretation of the situation. Defines the work based on the symbols given by the community in localizations and guests, thereby interpreting their work as the seller himself. Working as not only for economic needs but also as pride, they interpret the work as pride if they get a lot of guests. Pride becomes identified through the number of guests they serve. A large number of guests suggest that it has more physical beauty and sexuality than others. It is delivered KK (33 years), he said: "It was satisfied with his success Kalo had a lot of them. It means good game KK. Lagian loved by the same Mami because Mami also Gede. Then KK can dapet a lot of money for family, not important for me education. Especially religious knowledge. I am religious, but the most important thing is my income in a day can increase ". Basically, a job done by a woman is synonymous with bad things in society. This happens because society gives different assessments of the work done by women. A bad job in society will get a negative understanding in society (Sri Rahmadani, 2017).

The value of sexual transactions based on the number of guests is pride for them. Pride manifested in the number of guests who want them and pride to be very good among friends. Primadona is a symbol of high appreciation for the environment of women who work as. Towards the age of 30 there is a special fear for a woman in the process of meeting sexual needs, because in this age range women will enter the menopause. Menopause women usually lose their reproductive abilities due to hormonal changes with aging. Generally the age of menopause women ranges from 45 to 55 years. When entering 7 years before this age they will lose their jobs. Young age has a very valuable meaning for, so many ways they do to defend their young age. The way they defend their young age begins in a logical way in a way that doesn't make sense. In fact, some of them are gaining religious ignorance, as have been schools of religious schooling, but it does not apply to them because the most important thing is how to make a lot of money in a day. Work as farmers in rural communities is considered better and more promising because their daily income is clear. at this time at this time farmers in rural areas experienced a few obstacles, so they were looking for the last job so they looked for other jobs that were considered more like joining playmates and peers as karaoke guides and masher.(Tegar C Bahari, Akbar, and Rahmadani, 2020).

In general, women who work as dependent on the physical form to attract the attention of guests, therefore they take good care of their bodies. The physical attraction causes individuals to be accepted and liked by the community and is often the cause of greater achievement than what individuals might achieve if he has no appeal. Entering the 30s, start preparing plans to live in the future. For the young is a huge turnover to make money. This is the opinion of the seller himself. According 
to Blumer, it means that like this is the ability to think formed by social interaction. Through interactions with guests and the surrounding environment raises its own interpretation to.

Table 1. Age Range of WTS in Andam Dewi 2019

\begin{tabular}{cccc}
\hline Origin & Age & \multicolumn{2}{c}{ amount } \\
\cline { 3 - 4 } & & $\mathbf{2 0 1 7}$ & $\mathbf{2 0 1 8}$ \\
\hline West Sumatra & $17-20$ & 38 & 40 \\
& $21-24$ & 20 & 24 \\
Outside West Sumatra & $>25$ & 3 & 5 \\
& $17-20$ & 10 & 11 \\
& $21-24$ & 6 & 7 \\
& $>25$ & 2 & 4 \\
& Total & $\mathbf{7 9}$ & $\mathbf{9 1}$ \\
\hline
\end{tabular}

Source: Office of Social Services and Labor 2019

According to the table above, it can be seen that there has been an increase in the number of women netted during raids by Satpol PP. Dominant women aged 17 to 20 years are involved in prostitution. A total of 79 people were netted for 2017 from West Sumatera or from outside West Sumatera. The number increased to 91 people who were trapped in raids at 2018. Those affected raids were all brought to the localization of the goddess Andam. From the data above are generally those who are netted are minang women who are famous for the traditional philosophy of adat basandi sarak, sarak basandi kitabullah (ABS-SBK).

In Indonesia, the element of diversity can also be seen in ethnicity and race, religion and belief, ideology and politics, manners, economic disparities and social disparities. all of these elements are things that must be studied so that this diversity does not have a bad impact on social life in Indonesia (Janu Murdiyatmoko, 2007).

The percentage of religious education gained by the female Minang is derived from the school, but they are still very low schools in the figure below:

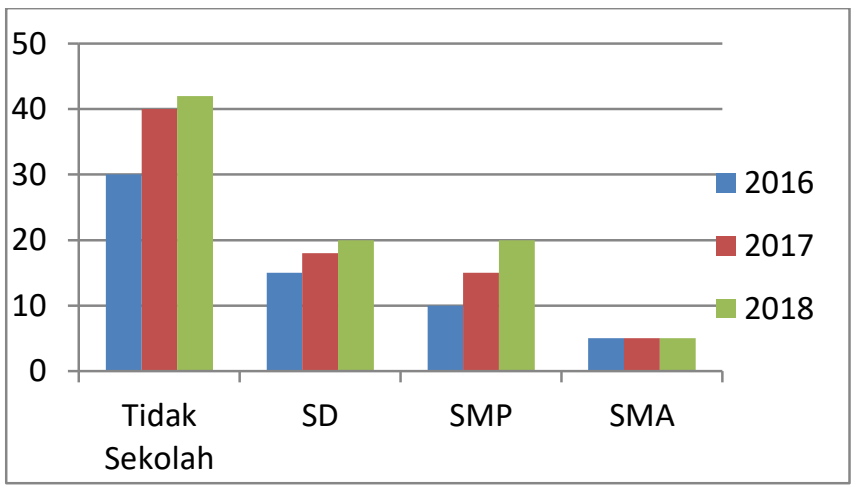

Source: Percentage of Religious Education Gained by Female's Minang From School

From the data above in general their education is very low, such as some who do not school at all. So the education gained in the field of religion, relatively little 
knowledge for society. So that later they are easy to fall in things that do not conform to the philosophy that has been highly esteemed by the Minangkabau people, namely the Adat Basandi Sarak, Sarak basandi Allaah (ABS-SBK). The government has done various ways that those who have been attacked so as not to return to the world of prostitution. Those who are netted in the the localization of Andam Dewi are equipped with various skills. As some are equipped with intelligence in sewing clothes, some are equipped with the ability to make food. However, from the fact of the find it turns out that almost $60 \%$ of them can not practice in life when they have come out of the localization. There are several reasons, firstly they do not have adequate capital, both of them have no enthusiasm for entrepreneurship, when they are used for prostitution, there is a sense of sexual need that should always be fulfilled because in general they do not have a husband. Another factor is the invitation of a friend who they cannot deny

\section{Conclusion}

Religious Education is very weak for women so they do not have a strong view of life. They know with the philosophy of ABS-SBK. And the role of Mamak does not go well. In the Andam Dewi women were involved in prostitution for several reasons. First, religious education is weak, and has a view that age and body are assets to work. The body is very guarded because they are the most important asset to them so they are willing to do logical or illogical things to defend their body and appearance. Secondly, everything that is not based on money. Third, religion is intended by as something sacred and sacred. They also realize that prostitution is a forbidden act by religion and is a sin act, but they still do the work. Their religious knowledge is very weak.

Economic factors form the basis of women involved in prostitution. In addition to economics, the authors also found that peer-to-peer and peer invitations were also the factors that caused prostitution. Therefore the number of women trapped in the localization of the Andam Dewi annually increased by $4 \%$. The internal and external factors that the authors find are the most dominant, i.e. external factors that reach $60 \%$. In fact, women who work as must be satisfied with their dissatisfaction. Because people in general already consider them humiliated, filthy, and disgusting humans. Their actions are considered worse than other actions such as selling the truth (honesty, fairness) including those done by officials or law enforcement. As well as the Government should be able to embed religious knowledge for Minangkabau people.

\section{Acknowledgement}

The authors say thanks to some Parties so that the author can complete this paper. The first for those who have provided data, namely Waza Karia Akbar, Yuhelna and Sri Rahmadani. Then to the relocation, he likes Solok, which has allowed its authors to display data especially to the head of relocation. Next the author thanked the research informant who gave the information during the interview of the woman in andam dewi, a religius education observer. In this study the funding that the authors use is purely personal funds because this research is independent 


\section{REFERENCES}

Afrizal. 2014. Metode Penelitian Kualitatif. Jakarta: Rajawali Pers.

Ahmad Tafsir. 2004. Ilmu Pendidikan Dalam Perspektif Islam. Bandung: Rosda Karya.

Aji, S. T. B., \& Heriyanto, H. 2013. "Pengaruh Layanan Perpustakaan Keliling Terhadap Kemampuan Literasi Informasi 'Wanita Tuna Susila (WTS)' Di Lokalisasi Gambilangu Semarang." Jurnal Ilmu Perpustakaan, 2(4):142-56.

Akbar, Waza Karia. 2018. "Socio-Economic Dependence of Peasant to Local Collector on Rice Farming System." Jurnal Ilmu Sosial Mamangan 7(1):23-31.

Akbar, Waza Karia. 2019. "Paddy Pangirai Woman in Nagari Sungai Janiah." Jurnal Ilmu Sosial Mamangan, 8(2):52-59.

Asmaini. 2018. "The Community Of the Building Was Dominated by a PSK That Was Caught in Padang,."

Budi Juliardi. 2014. Ilmu Sosial Budaya Sosial. Bandung: Alfabeta.

Dewi, Dian Suluh Kusuma, and Yusuf Adam Hilman. 2019. "Relokasi Pekerja Seks Komersial Setelah Penutupan Lokalisasi Kedung Banteng." JIP (Jurnal Ilmu Pemerintahan): Kajian Ilmu Pemerintahan Dan Politik Daerah 4(1):1-12.

Emzir. 2012. Analisis Data: Metode Penelitian Kualitatif. Jakarta: Rajawali Pres.

Erianjoni, Ikhwan. 2012. "Pola Dan Jaringan Prostitusi Terselubung Di Kota Padang." Humanus 11(2):112-18.

J. Moleong. 2007. A Quantiative Research Methodology. Bandung: adolescant rosda works.

Janu Murdiyatmoko. 2007. Sosiologi: Memahami Dan Mengkaji Masyarakat. Bandung: Grafindo.

K. Kartono. 2014. Social Pathology. Jakarta: Rajawali Pres.

M. M. McLaughlin, M. C. Lee, B. J. Hall, M. Bulterys, L. Ling, and J. D. Tucker. n.d. "Improving Health Services for African Migrants in China: A Perspective on Health Diplomacy." Glob. Public Health. 2014, 9(5):579-89.

Ramayulis. 2004. Llmu Pendidikan Islam. Jakarta: Kalam Mulia.

Ritzer, George dan Goodman, Douglas J. 2010. Teori Sosiologi: Dari Teori Sosiologi Klasik Sampai Perkembangan Mutakhir Teori Sosiologi Post Modern. Yogyakart: Kreasi Wacana.

S. Barmania. 2013. "Thai Migrant Sex Worker Struggling to Access Health Care," Lancet,." Lancet 382(9891):493-94.

Sri Rahmadani. 2017. "Analisis Struktur-Agensi Sumber Pendapatan Ganda Petani Miskin.” Jurnal Ilmu Sosial Mamangan 6 ( 1 ):11-22.

Tegar C Bahari, Waza Karia Akbar, and Sri Rahmadani. 2020. "Permasalahan Pemberdayaan Masyarakat Pertanian Melalui Usaha Tani Di Nagari Pasir Talang." Community 6(2):120-31.

W. S. Ramadhani, S. Sulastri, and S. A. Nurhaqim. 2017. The Process of Social Rehabilitation of Women in the Social Rehabilitation Hall of Women (BRSKW) Palimanan Cirebon District," in the Proceedings of Research and Devotion Tosociety. 